\title{
The Role of Accountability Arrangements in Social Innovations: Evidence from the UK and Slovakia
}

\author{
Juraj Nemec ${ }^{1}$, Marta Orviska ${ }^{2}$, Colin Lawson ${ }^{3}$
}

\section{Abstract}

Our research focuses on selected accountability mechanisms in the two countries. In Slovakia these are the Supreme Audit Office (SAO) and the Ombudsman. In the UK, at the national level we chose the Committee of Public Accounts (PAC), the National Audit Office (NAO) and the Parliamentary and Health Service Ombudsman (PHSO) and on the local level the relatively recently introduced local government system of Scrutiny and Overview.

The goal of our article is to assess the potential contribution of these accountability arrangements to the anchoring of social innovation in the public sector. The theory anticipates that accountability institutions such as the SAO and Ombudsman may create feedback loops supporting public innovations. We undertook detailed checks on the concrete situation in the Slovak Republic and in the UK. On the basis of the comprehensive set of data reviewed, including reports, interviews and more generally available information, we can confidently conclude that while in Slovakia such a feedback loop barely functions, in the UK it does function on a limited but still significant scale. In the last part we provide selected arguments why the Slovak situation is less positive.

\section{Key words:}

innovations, social innovations, accountability mechanisms, United Kingdom, Slovakia

1 Professor, Faculty of Economic and Administration, Masaryk University Brno, Czech Republic and Faculty of Economics, Matej Bel University Banska Bystrica, Slovakia.

2 Professor, Faculty of Economics, Matej Bel University Banska Bystrica, Slovakia.

3 Senior lecturer, Honorary Reader in Economics, University of Bath, United Kingdom and professor Faculty of Economics, Matej Bel University Banska Bystrica, Slovakia. 


\section{Introduction}

Public-service innovation is best understood as their development to better meet needs, by modifying the status of entities/actors in the system of public-service provision (Hartley 2005; Mulgan and Albury 2003; Osborne and Brown 2005). These entities are able and willing to learn, to improve their work and to cooperate with each other (Von Hippel 2007). Such innovation must meet the needs of society or of a specific community whose members are involved in the process of creation and implementation of innovation.

Innovation of public services is possible in the environment of a new concept of government that is defined as the sum of interactions with cooperation of actors from the public and private sectors in solving social problems (Osborne and Brown 2005). The emphasis is on the citizens and on building the civil society (Pollitt and Bouckaert 2011). This means that for innovation in the public sector to be successful, there must be a consistency between the nature and the environment where innovation takes place. A successful innovation process requires legitimacy (Wilson 1989), political sustainability (Moore and Hartley 2008), strengthening democratic values (Bason 2010) and respect for the needs of citizens (Korteland and Bekkers 2008). Public-sector innovation is social innovation that raises the economic, legal and democratic value of public services.

Bekkers (2013) provides the framework for our research. He defines social innovation in its public-sector context and identifies numerous potential drivers for and barriers to public sector innovation. These drivers and barriers are grouped in three main dimensions: the innovation environment, the innovation process and the adoption of innovation.

Our research focuses on selected accountability mechanisms in the two countries. In Slovakia these are the Supreme Audit Office (SAO) and the Ombudsman. In the UK, at the national level we chose the Committee of Public Accounts (PAC), the National Audit Office (NAO) and the Parliamentary and Health Service Ombudsman (PHSO). To complement them we chose to study the relatively recently introduced local-government system of Scrutiny and Overview.

The goal of our article is to assess the potential contribution of these accountability arrangements to the anchoring of social innovation in the public sector (Figure 1) using the example of two different countries: the UK - a developed country with a case-law system - and Slovakia - an EU country (in reality still a country in transition) with a continental law system. 


\section{Figure 1}

The role of accountability arrangements in social innovations

Feedback loops (accountability mechanisms, such as ombudsmen and audit offices)

Organisational learning

Source, authors, based on LIPSE project results

The general expectation is that accountability mechanisms such as ombudsmen and audit offices, if appropriately organised and well respected, can generate feedback loops which foster organisational learning. In turn these learning processes may increase the likelihood that innovations are anchored. Relevant research questions are:

- Which accountability and feedback mechanisms are in place, and how are they organised?

- Do accountability bodies facilitate organisational learning?

- If yes: are certain innovations institutionalised? If no, or only to a limited degree, why is that?

\section{Research methodology}

The research methodology is mainly based on qualitative methods and involved five stages - choosing the reports for analysis, analysing the reports' contents, selecting cases for in-depth interviews, applying questionnaires and summarising results.

Choosing the reports to analyse involved finding reports that had clear recommendations for change. In auditing terms we were looking more for performance audits than for compliance audits. To test whether a recommendation has been implemented it helps if the recommendation is clear. But testing for implementation means that the report probably has to have been issued some years earlier. For even if an auditee agrees to implement a recommendation, immediate compliance may be infeasible. But the passage of time can also mean the audit team has disbanded and left the audit organisation, thus making it impossible for us to interview them. This prevented us from completing a second NAO case study.

The content analysis of the report helps to decide its importance for our purposes and can throw extra light on the issue of whether or not there is evidence of feedback loops between the two parties. It can also suggest policy changes that may encourage innovation by the auditee.

If the report is of some significance and enough time has passed for a sensible evaluation of whether its recommendations were adopted, then we set about col- 
lecting detailed evidence about the relationship between the auditor and auditee using a very extensive questionnaire. This was achieved by face-to-face interviews or by email and telephone contact.

\section{Key institutions}

\section{Supreme Audit Office of the Slovak Republic (SAO: www.nku.gov.sk)}

The legal base for SAO functioning is the Act of the National Council of the Slovak Republic No 39/1993 Coll. of Laws on the Supreme Audit Office of the Slovak Republic as amended by Act No 458/2000 Coll. of Laws, Act No 559/2001 Coll. of Laws, Act No 385/2004 Coll. of Laws, Act No 261/2006 Coll. of Laws, Act No 199/2007 Coll. of Laws, Act No 659/2007 Coll. of Laws and Act No 400/2009 Coll. of Laws. The core relevant parts of this law are as follows:

The Office shall audit the management of budgetary funds approved under the law by the National Council of the Slovak Republic or by the Government of the Slovak Republic, property, property rights, funds, obligations and claims of state, public law institutions, the National Property Fund of the Slovak Republic, municipalities, upper-tier territorial units, legal entities with capital participation of the State, legal entities with capital participation of public law institutions, legal entities with capital participation of the National Property Fund of the Slovak Republic, legal entities with capital participation of municipalities, legal entities with capital participation of upper-tier territorial units, legal entities established by municipalities or legal entities established by upper-tier territorial units, property, property rights, funds and claims provided to the Slovak Republic, legal entities or natural persons under development programmes or for other similar reasons from abroad, property, property rights, funds, claims and obligations, for which the Slovak Republic has assumed guarantee, property, property rights, funds, claims and obligations of legal entities carrying out activities in the public interest.

The Office shall carry out audits with regard to compliance with generally binding legal regulations, the economy, effectiveness and efficiency, and it may make recommendations to audited entities and to relevant bodies on how to deal with weaknesses and shortcomings identified during the exercise of its competence - however, it has no right to decide about any fines. The authority to which weaknesses and shortcomings identified by the audit have been communicated by the Office shall be obliged, within the scope of its competence and within the time period specified by the Office, to ensure the removal of the identified weaknesses and shortcomings and to submit, without delay, to the Office a written report thereof.

The SAO is one of the most active Slovak CAF participants, and it received two national prizes for its quality-management system. The last financial and HRM data about the SAO are provided by the 2012 yearly report. According to it, in 2012 
the SAO employed 290 persons, 278 of whom were civil servants. Its 2012 budget was 7,785,243 EUR. The organisational structure consists of 6 sections (four auditdelivering sections, a section for economy and informatics and a strategic section), and the SAO has 8 antennas, one in each region.

\section{Ombudsman of the Slovak Republic (www.vop.gov.sk)}

The scope and scale of the rights and responsibilities of the Slovak Public Defender of Rights (Ombudsman) are defined by Article 151a of the Slovak Constitution. The Public Defender of Rights is an independent body that, in the scope and in manner laid down by a law, protects the fundamental rights and freedoms of natural persons and legal entities in proceedings before public-administration bodies and other public bodies, if activities, decision-making or inactivity of the bodies are inconsistent with legal order. In cases laid down by a law the public defender of rights can participate in calling to responsibility the persons acting in public bodies, if the persons have violated fundamental right or the freedom of natural persons and legal entities. All public power bodies shall provide the public defender of rights with needed co-action. The public defender of rights can apply to the Constitutional Court of the Slovak Republic for the commencement of proceedings according to Art. 125 if the fundamental rights or freedoms acknowledged for a natural person or legal entity are violated by a generally binding legal regulation.

In 2014 the Office of the Ombudsman employed 28 civil servants; 24 of whom directly participated in professional investigations. It also employed an administrative staff of 12 . The approved 2014 budget was 1,117,770 EUR, of which about 800,000 EUR were salary costs.

\section{The UK National Audit Office (NAO: www.nao.org.uk)}

The NAO is completely independent of government and is tasked with examining public expenditure on behalf of Parliament, to whose Committee of Public Accounts (PAC) it reports. Its head, the Comptroller and Auditor General (C\&AG) has the right to examine and audit government and public-body accounts and is an Officer of the House of Commons. Neither he nor his staff of 822 (2013-2014), most of whom are accountants, is a civil servant. The NAO is overseen by a parliamentary committee, the Public Accounts Commission. This body appoints the auditors for the NAO and considers and presents the estimated expenditure requirements of the NAO to Parliament. It also appoints non-executive members to the NAO's board.

In 2013-2014 the NAO certified 427 accounts for 355 organisations, thus assuring $£ 1$ trillion of income and expenditure, and by its own account saving the government an estimated $£ 1.1$ billion. $67 \%$ of audited bodies agreed that that the NAO "improves their approach to financial management and control". It produced 66 Value for Money (VFM) reports and 4 reports on local services. The PAC held 60 
hearings based on NAO work, and the government accepted $86 \%$ of PAC recommendations

The priorities of the NAO are to help government base its decisions on reliable comprehensive and comparable data, to improve its financial management and to help departments better understand the process and costs of delivering their services. "We define good value for money as the optimal use of resources to achieve the intended outcomes. Our role is not to question government policy objectives, but to provide independent and rigorous analysis to Parliament on the way in which public money has been spent to achieve those policy objectives" (http://www.nao. org.uk/about-us/what-we-do/value-for-money-programme/what-is-a-value-formoney-study?/ last accessed 27 January 2015).

In trying to achieve its priorities the NAO aims to use the best available techniques and, where appropriate, to be innovative approaching the investigations. They may employ outside specialists, and an investigation generally takes from 3 to 12 months. The investigation commonly uses financial and management analyses, document and literature reviews plus information from departmental and other staff, as well as from practitioners and service users, and benchmarking with other organisations at home or abroad. The full VFM cycle is consistent with the introduction and anchoring of social innovation in the public sector, which is summarised on the NAO website as follows:

- C\&AG selects subjects to examine on the basis of advice from NAO teams.

- The study team scopes the study and plans what methods will be most appropriate to deliver the study's objectives.

- The study team carries out the study according to an agreed timetable and budget.

- The study team drafts a report including a conclusion on value for money and recommendations for improvements.

- The factual content of the report is discussed ("cleared") with the audited body.

- The report is laid in the House of Commons and published.

- The report is the basis for a hearing of the Committee of Public (PAC), which publishes its own report.

- The Government responds formally to the PAC report, indicating what it will do to implement the committee's recommendations.

- The NAO assesses what action has been taken in response to each of the PAC reports and where appropriate may undertake a follow-up study to scrutinise the response in detail.

The VFM process is itself subject to quality assurance through internal peer review and external independent expert review. The intention is that the finished 
review be the product of a robust methodology, and so has clear defensible conclusions, and that $\mathrm{NAO}$ will drive improvements in public service.

\section{The UK Public Accounts Committee}

\section{(PAC: www.parliament.uk/business/committees/committees-a-z/ commons-select/public-accounts-committee)}

The PAC was created in 1861 on the orders of the then prime minister W. E. Gladstone. It has long been one of the key scrutiny committees of the UK parliament. Because it was created to examine government finances it is logical that a Treasury minister sits on the committee. But by convention the minister does not attend its meetings, presumably to preserve the appearance of the penultimate auditee not influencing the discussion of a key auditor. Nevertheless the Government's responses to PAC recommendations are conveyed to the PAC in what are called Treasury Minutes. When the Minutes give the response they are both logically and sensibly framed as coming from the ultimate auditee, the Government, as in "The government agrees with the Committee's recommendation". Of course the government does not have to agree, and often it does not.

The House of Commons appoints the PAC to examine "the accounts showing the appropriation of the sums granted to Parliament to meet the public expenditure, and of such other accounts laid before Parliament as the Committee may think fit" (Standing Order No 148). Its focus is on VFM, and any attempt to consider how policy was made or question whether it should have been different is vigorously rejected by the Treasury. Such questions are the concern of the Parliamentary select committees. As intended this prohibition is hard wired into the NAO's behaviour.

The PAC is a key part of the process of guaranteeing the transparency and accountability of government financial transactions. To strengthen the rigour of the scrutiny by the PAC and to distance its public image from that of the government the convention is that the PAC is chaired by a senior opposition politician. The Committee is assisted by the Comptroller and Auditor General, who is ever present and available to give evidence at Committee meetings, and by his NAO staff. The NAO staff assist the Committee in preparing their reports and provide them with briefings.

\section{The UK Parliamentary and Health Service Ombudsman (PHSO: www.ombudsman.org.uk)}

The ombudsman system in the UK dates from the 1960s and was loosely based on Scandinavian practices. Originally it was designed to investigate complaints of unfair treatment or inadequate service by UK central-government departments and some agencies. Access to its complaints mechanism was and somewhat controversially still is through a complainant's member of Parliament. In effect this means that the PHSO cannot conduct investigations into central government on 
its own initiative, and that weakens its power and effectiveness significantly. There is some pressure, not least from its present leadership, for complainants to have direct access to the PHSO, as they do for their complaints about the National Health Service (England). The NHS was added to the PHSO's remit in 1993 and now accounts for $80 \%$ of its work.

In the PHSO's view its work is part of the administrative justice system and accountable directly to Parliament. Their investigation of people's complaints gives people a voice and some power. It can recommend how organisations should remedy errors and can ask them to produce action plans to do so. But although its decisions carry considerable weight it cannot enforce them. However, significantly large or repeated issues can be reported to Parliament, which can hold them to account.

The Ombudsman's Annual Report and Accounts 2013-14: A Voice for Change reported that in 2012-13 it had received 27,566 enquiries that had resulted in 2199 investigations, 49 of which were conducted jointly with the Local Government Ombudsman (LGO see below). It upheld 854 of the complaints. Its budget was $£ 35$ million, and it published 22 reports, including 6 with the LGO. It expected that by 2014-15 it would have the capacity to investigate 4000 cases a year. By the end of March 2014 it had the equivalent of 427 full-time staff members. As it works jointly with the LGO we include a brief account of that organisation.

\section{The UK Local Government Ombudsman (www.lgo.org.uk)}

Over the last half-century the Ombudsman system has evolved by expanding to cover a wider range of areas of administration, often by the creation of new ombudsman positions covering more specialised areas of activity. The Local Government Ombudsman was created in 1974 and in 2013-14 registered 20,306 new complaints and enquiries, of which 11,725 were considered, and 5680 of those eventually passed to an investigation team. Of those $70 \%$ were dealt with in 13 weeks, $90 \%$ in 26 weeks and almost $100 \%$ within 52 weeks. $46 \%$ of the complaints dealt with in detail were upheld and $60 \%$ of the customers were satisfied or very satisfied with the service. The operating expenditure of the service in $2013-14$ was $£ 12.2$ million, and there was a staff of 161 .

Since April 2013 the Commission has published all of its decisions, save for those where publication might reveal the complainant. Publication increases the transparency of the decision-making process and the accountability of the service.

The jurisdiction of the commission includes all local authorities except parish and town councils, police and crime bodies, school-admission appeal panels and many other bodies providing local services. The vast majority of complaints concern the decisions of local authorities. Central-government administration is covered by the separate Parliamentary and Health Service Ombudsman, although both ombudsmen sit on each other's committees and conduct joint inquiries where a complaint falls under both competences. They are concerned to investigate mal- 
administration and injustice and to encourage appropriate remedies. "Although we cannot make bodies do what we recommend, they are almost always willing to act on what we say" (http://www.lgo.org.uk/about-us/ last accessed 28 January 2015).

From the viewpoint of the study perhaps the most interesting aspect of the Local Government Ombudsman's work is their focus on promoting best practice. This objective has been partly met by their recent decision to publish every decision they reach. Even more importantly, in 2013-14 58 detailed reports of investigations were published because the cases involved issues of wider public interest. "By publishing such cases we seek to ensure that all local authorities apply the lessons to their own councils and learn from the experiences of people in one area to inform service improvement in another" (ibid.).

\section{Overview and Scrutiny in UK Local Government}

Overview and Scrutiny committees were established in English and Welsh local authorities by the Local Government Act 2000. They were intended as a counterweight to the new executive structures created by that Act (elected mayors or leaders and cabinets). Their role was to develop and review policy and make recommendations to the council (Sandford 2014). Current committees operating in England draw their powers from the Localism Act 2011. Other regions operate under different legislation or, in the case of Scotland, no legislation, though many local authorities there have such committees.

In addition to committees scrutinising the operation of local administrations there are local-authority-managed scrutiny committees covering activities that lie outside the local authority's responsibilities. In England they have the power to scrutinise health bodies, crime and disorder partnerships, Police and Crime Commissioners and also flood-risk management bodies. In recent years the number of such scrutiny bodies has expanded, along with the policy to devolve powers away from central government. One such policy has been closing the Audit Commission, which dealt with local-government from April 2015 and local authorities are now free to engage private auditors. Some have argued that this strengthens the case for the creation of Local Public Accounts Committees to examine the whole range of publically financed activities in an area, mirroring the national PAC. If such committees are created, and that is not the present government's intention, though it is the policy of the opposition, then there is a strong case for either extending the NAO's remit or creating a similar body to advise local PACs.

Before the Local Government Act 2000 local authorities conducted their business through committees or meetings of the whole council. After the act all local authorities had to have at least one "scrutiny officer", though there was no provision to finance the post. Finance has remained a problem to the present day. While larger authorities were to introduce a range of scrutiny panels, district councils in England and Wales with fewer than 85,000 inhabitants could opt for a "streamlined commit- 
tee system" with at least one overview and scrutiny committee. With the passage of the Localism Act 2011 this option was extended to all English local authorities and many have reverted to the government by committee system. In Wales the Act mandated the opposite choice and required all councils to have either an elected mayor or a leader and cabinet system. The upshot of the Act and others covering Northern Ireland and Scotland is a great variety of local-government models across the country, as well as a range of scrutiny models.

The scrutiny system's structures and outcomes are thus varied and sometimes complex, which makes generalisation difficult. The Centre for Public Scrutiny (www.cfps.org.uk), an independent charity, has produced over 200 reports and other publications since 2004 and is a good source for research and for practical guides to accountability, transparency and involvement. It also produces good practice advice and give out the annual Good Scrutiny Awards, as well as less frequent surveys of the field. Common problems are a shortage of resources, lack of access to information, insufficiently robust criticisms of leadership and senior managers who do not value scrutiny efforts and evade challenges.

In Bath and North East Somerset (BANES), a local authority in the west of England with an estimated population of 178,000 , the Overview and Scrutiny system is referred to as Policy Development and Scrutiny and is operated by six panels. This is our local-government case-study area for scrutiny. The panels are

- Early Years, Children and Youth

- Economic Community Development

- Housing and Major Projects

- Planning Transport and Environment

- Resources

- Wellbeing

The panels' membership is drawn from elected councillors who are not Cabinet members. The "Overview" part of their remit is to help with policy development, comment on issues raised by the Cabinet, input into the early stages of major reviews of services and comment on draft budget and service plans. The "Scrutiny" activities include using performance-management information to check that targets are being met and action plans followed, to question certain Cabinet or officer decisions that have not yet been implemented, to check that certain Cabinet decisions are consistent with Council policies and plans and to evaluate the effects of Council or Cabinet policies and decisions.

The Overview and Scrutiny panels are thus not decision-making, but recommendation-making. They can co-opt extra non-elected members for specific investigations and can engage the public in their work. But they do not deal with individual citizens' queries or with their complaints: these are handled by other council services. Neither do they cover regulatory or quasi-judicial decisions, such 
as planning or licensing. Finally there is a separate Health Scrutiny Panel that now operates under powers derived from the Health and Social Care Act 2012 to make recommendations to improve health-care delivery.

We investigated five of the reports produced in recent years, gathering information from those who participated in their production.

The annual reports of BANES's Policy Development and Scrutiny panels are available at

http://democracy.bathnes.gov.uk/ecCatDisplay.aspx?sch=doc\&cat=13203\&path=0.

The reports are collected in a review archive at

http://democracy.bathnes.gov.uk/ecCatDisplay.aspx?sch=doc\&cat=13202\&path=0.

The review archive also contains the Cabinet's responses to the reports' recommendations. These have to be delivered within two months of receipt of a report. On average a panel will produce a report about every eighteen months.

\section{Do accountability mechanisms foster learning?}

We tackle this question by looking for evidence in the reports of the audit and scrutiny organisations whose activities were outlined in the previous section and in our questionnaires to those who worked on the audits or had knowledge of them. Unless otherwise indicated direct quotations are from questionnaire answers. We begin with two Slovak institutions and continue with the UK - the $\mathrm{NAO}$, and then the PAC, PHSO and BANES PDS panels. We draw some final conclusions in the next section.

\section{Supreme Audit Office, Slovakia}

The Slovak SAO is a Common Assessment Framework quality-management-system user and has received several awards for its quality initiatives. The representatives of the SAO are very proud of the quality of its audit activities - an interviewed director felt that it performed excellently. However, the reality is very different, as our research and also other sources indicate. Even the interview at the SAO revealed several major problems, especially:

- Before 2011 performance recommendations were not archived. This made tracing implementation difficult.

- Since 2011, although performance recommendations are archived, there is no system to trace implementation. So although reports may include important proposals, the SAO does not follow them up.

- The director feels very strongly that the SAO's role is that of a watchdog.

Our content analysis clearly documented that the SAO's auditors were not always fully qualified to deliver performance audits. We were satisfied that although 
the SAO carries out in-depth investigations and selects the right cases, it does not always select the right criteria. For example, many officially mixed compliance and performance audits were really just compliance audits. When checking performance audits, or the performance parts of audits, we found a few excellent reports. But we also found some with major deficiencies. For example the following quotes from two reports highlight the auditors' limitations:

"The city purchased cars for the lowest price. This means that economy, efficiency and effectiveness are secured."

"For each audited university we randomly selected areas for economy evaluation. In UKF Nitra we found that there was no exact paper evidence of the presence of staff in their offices."

The main principles for communicating SAO findings are prescribed by law. Draft reports must be discussed with the audited bodies at a joint meeting. The audited bodies must sign the final protocol (with the right to record disagreements). The elected management bodies of audited organisations must discuss SAO reports at regular meetings. SAO reports are fully available to the Parliament, and the SAO also has a dedicated department for communicating with the media and the public.

The positive finding is that there is some potential for the establishment of learning loops - all the organisations interviewed indicated that the SAO proposals in our three selected cases were apposite and helpful. But only about ten of the more than one hundred performance reports we analysed had these characteristics.

\section{Slovak Ombudsman}

According to the relevant legislation noted above, the core role of the Ombudsman is acting upon a complaint of a natural person or legal entity or on his own initiative in cases when fundamental rights and freedoms were infringed, contrary to the legal order or principles of the democratic state and the rule of law in relation to the activities, decision-making or inactivity of a public-administration body. This legislative environment means that the main role of the Ombudsman has an ex-post character, and there are significant limitations to the use of owninitiative investigations.

However, the Ombudsman also states on their office's main website that their role includes improving public-sector functioning - so there is some space for innovative proposals:

"I wish the state would function for the people and in terms of the democratic principles of good governance. I consider it very important, and accordingly I would also like to markedly contribute to the improved operation of the public-administration bodies. I will devote my energy and time above all to making 
our country a really good place for life and to making people feel better here."

JUDr. Jana Dubovcová, Public Defender of Rights

The analysis of Ombudsman reports indicates that a part of regular and specific Ombudsman reports are recommendations. Most of these recommendations have basic defensive or organisational character, but some of them may serve as motivation for public-sector innovations. However, we have to mention that the Ombudsman does not have a sufficiently pro-active communication strategy, especially concerning innovative proposals. All proposals are reported by two basic channels:

- annual regular reports - submitted to Parliament

- extraordinary specific reports on own initiative - with the right to move this document forward to be discussed in Parliament

Findings and proposals may but must not be discussed with bodies involved - all depends on the Ombudsman's decision (the Ombudsman also stressed that even in cases when she wants to discuss some issues, it is rather difficult to find a real partner - especially the Ministry of Labour and Social Work is not open for any communication). One employee of the Ombudsman Office is responsible for the contact with media, but the effectiveness of such efforts varies case by case.

All findings above indicate that there is relative potential for the establishment of a learning loop on the basis of the Ombudsman's recommendations. The Ombudsman is ready to serve in this direction, as our interview shows (our interviews with Ombudsmen seem to serve as the tool to strengthen this mechanisms), but a lot depends on the willingness of responsible public bodies.

\section{National Audit Office, UK}

The first report we considered was for the Ministry of Justice, entitled "Financial Management Report 2011" (http://www.nao.org.uk/wp-content/ uploads/2011/11/10121591es.pdf). Recommendation 1 suggests the need to improve the collection of fines, fees and assets under confiscation orders. There is strong evidence of an effective feedback loop here, because after the Ministry accepted the need to act the NAO found significant remaining problems and highlighted them in its December 2013 report on "Confiscation Orders". The Ministry then responded with further measures but "It is too early to know if this will provide a solution to the problem." The NAO feels that Recommendation 2, to improve its accounting management process, has been dealt with satisfactorily.

The process by which the original NAO report was dealt with is worth noting. The PAC felt this value-for-money report was sufficiently important to hold a hearing on it. Their report incorporated the NAO's suggestions and was accepted by the government in a Treasury Minute. The minute included a target implementation 
date. There are publically available documents that describe the process and hearings and give the results at each stage of the process. This is a standard procedure. "Our conclusions and recommendations are published in reports that are laid in Parliament. Our reports are accompanied by press releases to alert the media to our work. We discuss our conclusions and recommendations with our clients and they form part of the Committee of Public Accounts hearing on the report." We "want to offer expertise and respond to requests from the client ... We do not generate media coverage in order to put pressure on the organisations being audited."

We noted above that the NAO makes a bright-line distinction between investigating matters of administration and avoiding matters of policy. This distinction is mirrored in the work of the parliamentary committees. The parliamentary committee at whose meetings the policies of the Ministry of Justice are discussed is the Home Affairs Select Committee, and it is interesting to note that the NAO also "engages" with this committee.

The NAO's view of its role on the spectrum "Watchdog - Advisor" is clearly the former. But it does try "to build productive working relationships with organisations to help drive beneficial change. [For] we hold government departments and bodies to account for the way they use public money, thereby safeguarding the interests of taxpayers. [But] in addition our work aims to help public service managers improve performance and service delivery."

The second report we considered was the NAO's report on the Department for Environment, Food and Rural Affairs (DEFRA) "Managing Front Line Delivery Costs" (http://www.nao.org.uk/wp-content/uploads/2011/07/10121279es.pdf). Our investigation involved collecting evidence from the NAO group that dealt with this ministry, and the general impression of the NAO's role and culture was consistent with that from the Ministry of Justice report. This report was less high profile, and the PAC did not choose to hold a hearing on it. The Treasury Minute confirmed the Government's acceptance of the recommendations and set out a timetable for their implementation. DEFRA informed the NAO that implementation had been completed by 31 March 2013.

The NAO informant reported their view of DEFRA's learning culture as "fairly tolerant" and their cooperativeness as "ultimately ... high". The NAO undertakes what they call a clearance exercise when they agree all the key facts in their report with the client. "We also discuss tone and content where applicable. The Financial Director and Accounting officer both have an opportunity to comment." This process is clearly in part aimed at building the good working relationship that will facilitate change, noted by our informant on the Ministry of Justice Report. However it is worth noting that the decision to implement change lies with government. Ultimately responsibility is political. This is a pattern that repeats across the institutions we studied. 


\section{Committee on Public Accounts, UK}

Our report by this key audit organisation was their June 2014 report "BBC Digital Media Initiative" (52 ${ }^{\text {nd }}$ Report of the session 2013-14, HC 985). A second agreed study had to be abandoned because all of its authors had moved on from the PAC.

The $\mathrm{BBC}$ project was an expensive failed-investment project. The $\mathrm{BBC}$ failed to use competitive processes before signing a contract that later had to be no-fault

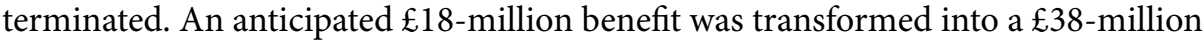
loss. The NAO identified very significant management weaknesses, but its investigation was delayed for eight months by the BBC's refusal to provide certain data on grounds of financial confidentiality.

The NAO report was sufficiently high profile for the PAC to schedule a hearing, and the result was a report that recommended changes in the governance of major projects and improved arrangements for challenging project performance. The PAC informant confirmed that parliamentary attention had helped produce a positive response from the $\mathrm{BBC}$. The $\mathrm{PAC}$ to some extent tailored its recommendations to their feasibility, and the BBC response was characterised as a "good solution". As part of this agreement the Treasury Minutes make it clear that in future the NAO would have an enhanced role in accessing and assessing BBC data and performance. This would include access to confidential contracts with third parties. The outcome thus involved significant innovatory change that was anchored in the auditing culture of this independent public corporation.

\section{Parliamentary and Health Service Ombudsman, UK}

The investigated report was "A False Economy: Investigations into how People are Recompensed for Government Mistakes" (http://www.ombudsman.org.uk/ reports-and-consultations/reports/parliamentary/a-false-economy-investigationsinto-how-people-are-compensated-for-government-mistakes/10) Here the auditee was the Planning Inspectorate, and our informant works for them.

In 2010 the Planning Inspectorate was forced to look for savings because it faced a $35 \%$ cut in its budget by $2014-15$. The cut amounted to $£ 9$ million. They decided to drop an ad-hoc compensation scheme that they had previously operated to compensate people who had suffered losses because of their mistakes. The annual saving would have been $£ 250,000$. The PHSO investigated a series of similar individual complaints and, realising that they had a pattern, issued a report that had a much larger potential audience than just the Planning Inspectorate.

The PHSO judgement was that "The Planning Inspectorate were acting contrary to HM Treasury guidance Managing Public Money and contrary to the Ombudsman's Principles when they decided that they would routinely refuse to pay compensation for the impact of their mistakes on users of their service." 
Although PHSO did not specifically make the suggestion to the Planning Inspectorate, the latter decided to reinstate the original compensation scheme. In addition the PHSO, as it does for all its reports, issued a Learning Points document on its website, aimed at Permanent Secretaries - the most senior civil servants in ministries -, Boards and Senior Managers. The Learning points warn about the dangers of false economies and the importance of fairness and equity when cutting expenditure. They urge these senior officers to consult the PHSO's Principles of Good Administration, Principles of Good Complaint Handling and Principles for Remedy when they are considering budget cuts. This was a timely reminder in the face of continuing and intensifying austerity.

The report directly resulted in a limited positive change and reinforced the importance of good communication across auditors and auditees. The PSHO clearly demonstrated its ability to effect change, and to generalise that change across its whole remit of organisations. There is evidence of learning and the chance for innovation.

\section{BANES Policy Development and Scrutiny Reports}

We selected five reports from four different panels. There were three participant informants, two of whom had served on two panels. The reports were:

- Boat Dwellers and River Travellers Review 2013

- Home Care Review 2011

- Home to School Transport Review 2012

- Community Assets 2013

- Review of the Council's use of Consultants 2011-12

Here we try to give an assessment of the five reports taken as a whole, particularly from the angle of learning innovation and anchoring change.

For four reports the Cabinet accepted almost all the recommendations, and if not accepted, a recommendation was usually just deferred. The informants were less likely than those at the national bodies we have already assessed to say that their recommendations were made with a view to their feasibility. However one noted that "Usually we have an idea from officers how Cabinet are likely to respond ... but this does not change the process."

The remaining report was the Boat Dwellers and River Travellers Review. This was a very innovative review into the significant minority community of boat dwellers who live on the rivers and canals of the area. Bath is unusual in having about one per cent of its population living on boats. They face rather different challenges to other householders. The review had 13 recommendations or parts of recommendations. Four were agreed, seven were deferred, and two were rejected. The problem of deferral was caused by the fact that some decisions will have to wait on river-safety improvements, and others were delayed because it was necessary to develop joint policies with other organisations with responsibilities for waterways. A new policy 
officer will be employed from January 2015 and this may help move forward the report's recommendations. The issues will need to be revisited in 2016 and 2017 and will require an evaluation framework to measure need and success, for example including families' state of health and access to schools.

The experiences of participants on the panels were generally positive. Our informants noted that Cabinet members were "very helpful and willing to cooperate at all stages" and they had "good working relationships and criticisms were taken seriously". There was "respect" between the participants. However one informant noted that the level of tolerance was "Not great. It varies with the cabinet member, age and experience." But the panels felt they had some power because "Panels have an input into budgets, and that gives them some influence. The reputation of the chair is important, but how the reputation is perceived depends on both sides' personnel."

Getting a recommendation accepted depended on cost: zero-cost recommendations are more likely to be accepted. "Changes are linked primarily to budget, political impact and timing - nothing too drastic before an election!"

It was clear that the panels have significant potential to introduce small alterations and changes in administration, and even innovations as refined by LIPSE. But what comes through clearly from reading the reports and talking to participants is that lasting changes require updates. We have noted this for the Boat Dwellers report, but it is more widely true. For example the 2010 Home Care Review is an impressive piece of work. BANES had switched from council to private provision of home care some years earlier, and the Healthier Communities and Older People Panel, which had monitored the situation since then, set out to discover "whether the five Home Care providers ... are achieving the Council's stated objectives for the service." An update on this review and its recommendations was produced in 2014, and a further update is planned for 2017. Such updating is a good indicator of the learning and anchoring potentials of the PDS panels' work.

\section{What is the real impact of the accountability mechanisms on public-sector innovations?}

The Slovak information and responses from eight interviewed organisations do not provide a very optimistic picture of the level of implementation of SAO and Ombudsman recommendations.

Concerning the SAO, in only one case (the municipality Helpa) did the mayor state that all the recommendations were welcomed and fully implemented. But our own investigation suggested his assessment was too positive. For example the municipality does not have the data needed to assess the level of separation, and neither was such data part of the programme budget. In other investigated cases respon- 
dents mentioned partial or zero implementation. The main excuse was financial constraints.

Another pertinent question is whether the SAO recommendations were the main, or at least an important, reason for changes. If we look at our cases:

- Changes in the public-transport system in Zilina were the result of EU-financed project conditions, not the SAO report, which had no impact.

- Improved separation of waste on a municipal level is mainly the result of new stricter EU legislation, setting legal requirements for recycling. SAO reports might play some role, but they are not the dominant driver of change.

- Banovce's new heating system also cannot be directly connected to SAO recommendations. SAO reports might play some role, but again they are not the dominant driver of change.

Municipalities do not screen SAO reports as a source of new ideas and innovations. For them the SAO is a watchdog, controlling the detail of their actions - not a partner helping them to improve local democracy and local public services.

Taking a cost-benefit view of the real impacts of SAO audit on public-administration innovation practice, we cannot be very positive. Of the several hundreds of reports we examined only a very few, including real recommendations with innovative potential, and in most cases this rather limited innovative feedback loop was neglected by the audited bodies.

Concerning the Ombudsman our research indicates that none of its innovative proposals are realised. To summarise, we conclude that the impact of the SAO and the Ombudsman on public innovations in Slovakia via effective feedback learning loops is rather limited because of the character of both institutions - perceived as controllers - and the general political environment, specifically the politicisation of the public-administration system. This last item is especially relevant in current Ombudsman cases.

For the UK this concluding section is partly summative and partly speculative. The summative part's message is to stress that there is a wealth of examples here of the fact that the UK audit, scrutiny and ombudsman system has very significant learning, innovation and anchoring functions, potential and actual. Some conclusions are:

- Routine, repeated audits improve the chances of change, of anchoring change and the chances of discovering dysfunctional behaviour.

- Parliamentary attention and Council attention can drive change.

- The national bodies in this area are probably better than local ones at spotting and acting on the more general applications of a particular finding. 
- The different models of local government and local-government scrutiny suggest that there could be a wide range of responses across local authorities to the same problem. It is not obvious why such variation might be optimal.

- Being able to conduct joint investigations across organisations increases the scope of change. For example the Parliamentary and Health Services Ombudsman and the Local Government Ombudsman can conduct joint investigations. There may be scope for considerable benefits with more inter-local authority joint investigations.

- There is a strong case for allowing Ombudsmen to initiate investigations in any area of their competence.

- The more authorities and other organisations monitor and publicise change the better the chance of change and of anchoring it.

- It is worth noting that the UK system, at the central and top-tier local levels, reserves to politicians the decision power for adopting recommendations. Powerful audit, scrutiny and ombudsmen organisations make suggestions but ultimately defer to Parliament. The NAO may now get ready access to the BBC's financial contracts, but only politicians will decide if the subsequent recommendations are adopted. It is consistent with democracy, but it is not the only way of managing such systems.

- Finally speculation - it is not clear that the "Watchdog - Advisor" distinction is going to be very productive in explaining learning, innovation and anchoring change, at least for the UK. Some of the key bodies, such as the NAO, see themselves as fulfilling both functions simultaneously. If forced to choose they opt for "Watchdog", but their language, and especially the use of "client" for auditee, and their view of their dual functions suggests "Advisor" as well.

\section{Possible reasons for the Slovak situation}

We argued above that the impact of accountability institutions and mechanisms on public innovations that we observed to a significant if limited extent in the UK is almost absent in Slovakia. We also argued that this absence might be due to the character and capacities of Slovak accountability bodies. In addition our research and other evidence points to additional explanations for the very limited quality of the Slovak innovations feedback loop. The explanations are:

1. A limited absorption (implementation) capacity on the part of addressed organisations.

2. A difficult Slovak environment, characterised by a lack of accountability and responsibility.

3. The over-politicisation of public life and the role of the media. 


\section{Absorption capacity}

The problem of absorption capacity has several dimensions, but the most noticeable is territorial fragmentation. Local governments not only feel that the SAO and the Ombudsman are just controllers, but they also harbour doubts about the capacity of the SAO to control and advise, and about their capacities to improve and to implement interesting advice. This situation is the result of excessive fragmentation in local government. Slovakia has 5.5 million people but almost 3000 municipalities, most with fewer than 1000 inhabitants. Such tiny administrative units have problems handling the basic daily tasks of municipal life, and their internal innovative capacity and absorption capacity for handling external innovation inputs is close to zero.

Larger public-sector bodies also have only a limited capacity to absorb positive suggestions for change, as our cases show. Zilina, for example, has almost 100,000 inhabitants. The main reason is described below. The other issue is lack of willingness of municipal leaders to co-operate with other stakeholders (see Nemec et al. 2015 or Merickova Mikusova and Svidronova 2014).

\section{Accountability and responsibility}

The second explanation - a problem specific to the CEE region - is their lack of accountability and responsibility. This has been well described by many recent studies - like Vesely (2013), Merickova and Stejskal (2014), Kattel (2015), Nakrosis (2015), Ochrana and Hrncirova (2015), Placek et al. (2015) and others. It is standard in Public Economics to argue that elected politicians may serve both the public and their own private interests (Stiglitz 1989). In Slovak conditions the second choice is rather common - and rent-seeking officials do not normally deliver innovations to improve administrative and public services. Of course if the innovations are costly and firms connected to the politicians may benefit, then that can change.

A study by Pavel (2009) clearly shows that because of their low level of accountability, Slovak public bodies frequently do not correct the mistakes discovered by SAO controls. And if such clearly emphasised errors are not rectified, it is hard to believe that SAO performance proposals would be implemented.

\section{Politicisation}

The Slovak public sector is clearly over-politicised. The SAO and the Ombudsman are themselves interesting examples. The SAO is rather popular with the current and indeed also the previous government. The current SAO president's term of office ended three years ago, and while it is Parliament's job to elect a new one, no political party shows any inclination to do so. We suggest that this is because it has been many years since the SAO initiated an investigation into any major top-level scandal. 
On the other hand, the reputation of the SAO in the eyes of external experts is not very high. A lot of evidence for this is visible from our contents analysis and from our interviews. In 2012 the SAO was reviewed by Transparency International in a large project covering several CEE countries (Kostal et al. 2012). It scored a relatively high global figure, but the lowest scores were for the following indicators:

"To what extent does the audit institution provide effective audits of public expenditure?"

"To what extent is the SAO effective in improving the financial management of government?"

The scores for the auditors from interviewed representatives of the audited bodies were also quite low. All of them saw the SAO as a watchdog, so the auditors were not able to do their work on the basis of trust and understanding. The average mark from this group for the SAO's reputation in terms of credibility and expertise is 3 (with 7 as the maximum).

The Ombudsman's position is rather different. During the interview the Ombudsman stated that:

"Political support can make Parliament more open to the suggested changes."

Because the Ombudsman has criticised several actions of the current government, she is currently "persona non grata" for the governing coalition, which has a clear majority in Parliament. The fact that the Ombudsman did not receive space for her requested interventions in the programme of recent Parliamentary sessions is clear evidence of the current antagonistic relations between the coalition and the Ombudsman's office (see, for example, Pravda, 30 January 2014: http://spravy.pravda.sk/domace/clanok/306921/).

The Ombudsman also stated:

"The Public Defender of Rights is expected to be the eyes and ears of Parliament. (However) ... The Public Defender of Rights is perceived by the institutions more like a control institution, and the primary reaction is to defend."

\section{Role of the Media}

The media's role reflects current society. The media are more willing to carry negative than positive stories. They attract a larger audience. That is true almost everywhere. But Slovakia, unlike most other advanced societies, has no real investigative and independent daily or weekly papers. Indeed only two owners dominate the news scene. This situation was alluded to by the Ombudsman when they said:

"Practical experience indicates that if some specific and unique issue is detected - the solution of such an issue is much quick- 
er compared to an issue which requires systematic change. It is much more difficult."

\section{Conclusions}

The theory anticipates that accountability institutions such as the SAO and the Ombudsman may create feedback loops supporting public innovations. We undertook detailed checks on the concrete situation in the Slovak Republic and in the UK. On the basis of the comprehensive set of data reviewed, including reports, interviews and more generally available information, we can confidently conclude that while in Slovakia such a feedback loop barely functions, in the UK it does function on a limited but still significant scale.

The several factors that determine the situation in Slovakia were briefly discussed in the final section above. To make the feedback loop operative in Slovakia there would need to be changes on many levels. In particular there would need to be improvements in the audit capacity of the SAO, less politicisation in the country's public administration and greater absorption and implementation capacities on the part of public bodies responsible for innovations.

Our article confirms the general assumption that well working accountability mechanisms have good potential to support the innovativeness of the public sector. However, it also shows that in specific conditions where accountability and responsibility are not real public values, the public sector is over-politicised and media have "boulevard" character, this process may not occur. The case of Slovakia includes one extra specific feature - large fragmentation: Slovakia has 5.5 million people but almost 3000 municipalities, most with fewer than 1000 inhabitants. Such tiny administrative units have problems handling the basic daily tasks of municipal life and their internal innovative capacity and absorption capacity for handling external innovation inputs is close to zero.

\section{Acknowledgement}

This research is supported by the LIPSE project. LIPSE, or "Learning from Innovation in Public Sector Environments", is a research project studying the drivers and barriers to successful social innovations in the public sector. The research is cofinanced at the local level by the APVV project DO7RP-0010-12.

\section{References}

Bason, C. 2010. Leading Public Sector Innovation. Bristol: Policy Press. 
Bekkers, V. 2013. "Social Innovation" in the Public Sector: An Integrative Framework. Rotterdam: Erasmus University.

Hartley, J. 2005. "Innovation in Governance and Public Services: Past and Present." Public Money \& Management 25(1), 27-34.

Kattel, R. 2015. "What would Max Weber Say about Public-Sector Innovation?" NISPAcee Journal of Public Administration and Policy 8(1), 9-19.

Korteland, E. and V. Bekkers. 2008. "Diffusion and Adoption of Electronic Service Delivery Innovations in Dutch e-Policing." Public Management Review 10(1), $71-88$.

Kostal, C. et al. 2012. Narodny system integrity spravovania: Hodnotiaca sprava. Bratislava: Transparency International Slovakia.

Merickova, B. and J. Stejskal. 2014. "Value of Collective Consumption Goods." Politicka Ekonomie 62(2), 216-231.

Merickova Mikusova, B. and M. Svidronova. 2014. "Co-creation in Public Services: An Alternative Public Service Delivery Arrangement.” In L. Sedmihradska (ed). Proceedings of the $19^{\text {th }}$ International Conference: "Theoretical and Practical Aspects of Public Finance 2014”. Prague: University of Economics, $188-196$.

Moore, M. and J. Hartley. 2008. "Innovations in Governance." Public Management Review 10(1), 3-20.

Mulgan G. and D. Albury. 2003. Innovation in the Public Sector. London: Strategy Unit Cabinet Office.

Nakrosis, V. 2015. “The Influence of Government Priorities on Public-Administration Reforms in Europe." NISPAcee Journal of Public Administration and Policy 8(1), 21-40.

Nemec, J., B. Mikusova Merickova and M. Svidronova. 2015. "Social Innovations in Public Services: Co-creation in Slovakia." In D. Spalkova and L. Matejova (eds). Proceedings of the $19^{\text {th }}$ International Conference "Current Trends in Public Sector Research”. Brno: Masaryk University, 273-281.

Ochrana, F. and K. Hrncirova. 2015. "Does the Lowest Bid Price Evaluation Criterion Make for a More Efficient Public Procurement Selection Criterion? (Case of the Czech Republic)." NISPAcee Journal of Public Administration and Policy 8(1), 41-59.

Osborne, S. and K. Brown. 2005. Managing Change and Innovation in Public Service Organizations. London: Routledge.

Pavel, J. 2009. Efektivnost fungovania kontrolnych systemov verejneho obstaravania na Slovensku. Bratislava: TIS. 
Placek, M., F. Ochrana and M. Pucek. 2015. "Benchmarking in Czech Higher Education." NISPAcee Journal of Public Administration and Policy 8(2), 101-124.

Pollitt, C. and G. Bouckaert. 2011. Public Management Reform: A Comparative Analysis. Oxford: Oxford University Press.

Sandford, M. 2014. "Overview and Scrutiny in Local Government." House of Commons Library, Standard Note SN/PC/06520, updated 22 December 2014.

Stiglitz, J. E. 1989. Economics of Public Sector. New York: Norton.

Vesely, A. 2013. "Accountability in Central and Eastern Europe: Concept and Reality." International Review of Administrative Sciences 79(2), 310-330.

Von Hippel, E. 2007. "Horizontal Innovation Networks - by and for Users." Industrial and Corporate Change 16(2), 1-23.

Wilson, J. 1989. Bureaucracy: What Governments Do and why they Do it. New York: Basic Books. 